\title{
INTERPERSONALITY AND CULTURE: AN APPROACH TO THE MOVIE REVIEW GENRE
}

\author{
Francisco Miguel Ivorra Pérez, Universidad de Valencia \\ Email: francisco.ivorra@uv.es
}

\begin{abstract}
This paper investigates the impact of cultural values on the interactional metadiscourse (Hyland and Tse 2004) used in movie reviews drawn from two digital newspapers: the Peninsular-Spanish El País and the British The Guardian. Specifically, the influence of Hall's (1976) "context dependence" and Hofstede's (1991) "individualism index" is surveyed. The findings reveal similarities for both corpora due to genre constraints, but cultural differences are also found. The implication of the study is to raise awareness of the importance of interpersonal metadiscourse as a persuasive linguistic element in the teaching and learning of L2 writing skills.
\end{abstract}

Keywords: Cultural values, cross-cultural communication, movie reviews, interpersonality, L2 ${ }^{84}$ writing skills.

Title in Spanish: Interpersonalidad y cultura: una aproximación al género de la reseña de película.

Resumen: Este estudio investiga el impacto de los valores culturales en el metadiscurso interaccional (Hyland and Tse 2004) empleado en reseñas de películas de dos periódicos digitales: el español peninsular El País y el británico The Guardian. Concretamente, exploramos el nivel de "dependencia contextual" de Hall (1976) e "índice de individualismo" de Hofstede (1991). Los resultados revelan similitudes en ambos corpus debidas a las convenciones del género así como diferencias culturales. La implicación del estudio es resaltar la importancia del metadiscurso interpersonal como elemento lingüístico persuasivo en la enseñanza y el aprendizaje de las destrezas escritas de una segunda lengua. Palabras clave: Valores culturales, comunicación transcultural, reseñas de películas, interpersonalidad, destrezas escritas de una segunda lengua.

\section{INTRODUCTION}

In the Common European Framework of References for Languages (CEFR) the concept of interculturality deserves special attention. This is associated with "how users of a foreign language are able to correlate their native culture with that of the new one to become multilingual speakers" (Council of Europe 2002: 45) ${ }^{85}$. In this sense, the terms culture and

84 L2 stands for "second language".

85 For further information on this issue, see the Common European Framework of References for Languages 
socio-cultural competence are closely linked (van Ek 1986). Following Giovannini et al. (1996: 29), the socio-cultural competence is defined as "the knowledge of the socio-cultural context where the target language is spoken and the ability to adopt the appropriate social strategies".

The movie review has been a professional written genre frequently taught in L2 classes of secondary and tertiary educational levels. Even though L2 teachers use to explain the appropriate genre conventions, they are not always able to describe why these may be stemmed from cultural factors that are not directly observable for speakers but govern the use of the target language.

Interpersonal metadiscourse stands out as one of the most crucial rhetorical elements that gives shape to many academic and professional genres. This is a valuable rhetorical element to express the writers' voice towards what they convey and the interaction they hold with their readers. In particular, the film review genre can be considered as a persuasive text in which writers try to convince their readers whether they want to watch, rent or buy a movie. It goes without saying that L2 learners could perfectly achieve a good linguistic competence when writing a film review in the target language. Nonetheless, it is our view that students' socio-cultural competence could possibly fail due to an inappropriate use of interpersonal markers, as these may be transferred from their native language and the persuasion on the target reader may not be achieved at all.

Providing that culture filters the way interpersonal metadiscourse is produced and interpreted in different languages, the way the target reader is persuaded to take a particular action may differ from that of the writer's mother tongue. Hence, we agree with Shokouhi and Talati (2009: 550) when they claim that "if a non-native learner wants to produce a more acceptable piece of writing should learn, besides the system of the L2 writing, conventions which operate on discourse and text level". In our opinion, these conventions may result from the target speaker's cultural and thought patterns.

\section{LITERATURE REVIEW}

van Ek (1986: 35) points out that "every language is situated in a socio-cultural context which triggers the use of a particular reference frame which is partly different from that of the foreign language learner". Students are then expected to become familiar with the cultural frame that governs the use of their mother tongue and that of the speaker's target language to communicate effectively in the cross-cultural scenario.

The concept of culture ${ }^{86}$ has received different definitions throughout the decades. Hofstede (1991: 4) refers to this term as "the collective mental programming of the mind distinguishing the members of one group or category of people from others". Gibson (2000: 7) considers culture as "a shared system of attitudes, beliefs, values, and behaviour". These definitions draw our attention to the way a particular group of people is trained from a very early age to internalise the behaviour and attitudes of the community.

(CEFR) http://www.coe.int/t/dg4/linguistic/source/framework_en.pdf

86 Scollon and Scollon (1995: 124) claim that, in English, the word culture may be used with two differentmeanings: (a) high culture and (b) anthropological culture. The former refers to intelectual and artistic achievements whereas the latter focuses on customs, worldview, language, kinship system, social organisation, etc. 
Researchers interested in the field of intercultural communication have proposed different theoretical paradigms to identify the basic social problems affecting all societies - cultural dimensions - but for which members of different societies may have different answers -cultural values (e.g. Hall 1959, 1966, 1976; Hampden-Turner and Trompenaars 1993; Hofstede 1991; Kluckhohn and Strodtbeck 1961). Despite the valuable contribution offered by the aforementioned researchers, we agree with Hoopes (1980, quoted in Bennet 1998: 6) when he states that "cultural generalisations can be made while avoiding stereotypes by maintaining the idea of preponderance of belief". According to Guillén-Nieto (2005: 107), this last idea highlights the fact "that each culture may have a preference for some beliefs over others". Additionally, one can find individual differences that deviate from the preferred cultural values of the group and hold beliefs similar to those of people in a different culture.

Most specialists also agree that the term culture and identity group or discourse community are interdependent. In this respect, Scollon, Scollon and Jones (2012) point out that speakers participate in different discourse systems embedded in their own cultures throughout their whole life (e.g. gender or sexual identity, a particular region or country, the historical period in which they live, their hobbies, etc.).

As regards L2 teaching and learning, the term culture is closely related to socio-cultural competence (van Ek 1986). To get this competence, learners need to acquire "the knowledge of the socio-cultural context where the target language is spoken and the ability to adopt the appropriate social strategies" (Giovannini et al. 1996: 29). In our opinion, the cultural dimension of context-dependence (Hall 1976) and the individualism index (Hofstede 1991) may be considered relevant examples of contextual variables which might influence the way communication strategies are produced and interpreted in different languages.

A pioneer in the study of the effect of context in meaning was North-American anthropologist Edward T. Hall, who, in his work Beyond Culture (1976), observed that the dependence of a message on its context varies between two poles of a continuum: high-context and low-context dependence. He observed that Spaniards are moderately high-context speakers who value an implicit communicative style which relies on the audience's ability to grasp the main message. In contrast, Britons prefer a low-context communication in which detailed and explicit messages are more important than contextual information.

Geert Hofstede's (1991) individualism index correlates with the concept of the self, namely "a concern for yourself as an individual as opposed to concern for the group to which you belong" (Hofstede 1991: 51).

The aforementioned Dutch engineer and social psychologist analysed a large data base of employee's values score collected by IBM between 1967 and 1973, covering more than 70 countries. He used the data to measure the degree of individualism or collectivism of people from different countries in the world using a 0 to 100 scale ( 0 corresponding to the most collectivist society and 100 to the most individualistic one). The results gave Spain and the UK a score of 51 and 89 points respectively, confirming a strong cultural difference between both countries. According to this, Spanish society may be considered a moderately individualistic culture, whereas Britons seem to hold highly individualistic cultural values.

Hofstede's research has latterly attracted a lot of criticism for being old-fashioned and liable to promote cultural overgeneralizations and stereotypes (Loukianenko-Wolfe 2008). 
Nevertheless, in the opinion of scholars like Clark (1990), Hofstede has provided the most comprehensive and influential study to date of how values in the workplace are influenced by culture at a 'collective' level.

The degree of context-dependence and the individualism index held by speakers from different countries could affect the production and interpretation of interpersonal metadiscourse in different languages, particularly in a persuasive professional genre like the movie review.

In film reviews, writers persuade potential readers to make an informed decision, without giving too much information on the plot. Some researchers (e.g. García 1985; Martín 1986; Morán 1988) confirm that movie reviews are similar to an opinion article from a newspaper because of the subjective criterion that the text reflects. Therefore, the set of communicative purposes which motivate writers to review a movie is the intention of giving their opinion about a particular film and express the elements they enjoyed or disliked. However, as in all good journalism, the reviewer should also provide impartial details, allowing the reader to make his/her own mind. To this end, a movie review must be well written for full impact with its local readers, attract their attention and persuade them either to watch or not to watch the film.

Regarding L2 teaching and learning, we think that most language learners can manage to produce a persuasive text fairly correct from a morpho-syntactic and lexical point of view after some training; however, they may find difficulties or even fail on the interpersonal level, not being able to make an appropriate transfer of the persuasive strategies they know in their own mother tongue into the target language. In other words, the intrinsic persuasive nature of interpersonal metadiscourse "may differ from one language to the other as the interpersonal function responds to different cultural patterns and filters" (Suau-Jiménez and Dolón-Herrero 2007: 72). This is why experts such as Shokouhi and Talati (2009: 550) advise students to reinforce the L2 cultural and shared-knowledge patterns, as mastering grammar and specific terminology may not be enough to succeed in the production or interpretation of a persuasive text.

Metadiscourse is one of the most persuasive linguistic elements to establish an interaction between the writer and the reader in many academic and professional genres. Following Hyland (1998: 438), the concept of metadiscourse is defined as "those aspects of a text which explicitly refer to the organisation of discourse or the writer's stance towards either the content or the reader". Despite some linguists limit the notion of metadiscourse to Halliday's (1975) textual metafunction of language (Mauranen 1993), others like VandeKopple (1985) and Hyland (2004) view metadiscourse from a double perspective: (a) textual and (b) interpersonal. The former refers to those linguistic features which organise discourse, anticipate readers' knowledge and reflect the writer's assessment of what needs to be made explicit, to constrain and guide what can be recovered from the text; the latter involves readers in the argument by alerting them to the author's perspective towards both propositional information and readers themselves.

In the present study, special attention is paid to interactional metadiscourse. Drawing on Hyland and Tse's (2004: 169) taxonomy, interactional metadiscourse includes different markers such as hedges, boosters, attitude, engagement and self-mention markers. Given their interactional nature, they become meaningful indicators of the degree of suitability or disparity that may exist between the cultural values expressed by the writer and those 
interpreted by the reader. These markers are influential cross-cultural rhetorical devices because as Hyland (1999: 5) says "engage and influence readers in ways that conform to the norms of a discipline, values and ideology of a community, thus expressing interpersonal meanings in a way to be credible and convincing to the audience of that community".

Various studies have examined the use of metadiscourse strategies from a cross-cultural perspective. Some of them have found that metadiscourse is often constrained by the conventions of the particular genre (e.g. Dafouz-Milne 2003; Moreno 1997; Mur-Dueñas 2010), but most of them agree that they are highly influenced by intercultural variation (e.g. Crismore et al. 1993; Junqueira and Cortés 2014; Mauranen 1993; Shokouki and Talati 2009; Suau-Jiménez, 2010, 2016; Valero-Garcés 1996).

The above-mentioned studies are embedded within the discipline of intercultural pragmatics. Although the birth of this discipline dates back to the 70 s and 80 s with a reaction against the alleged universalism of certain linguistic theories of Anglo-Saxon origin (e.g. Brown and Levinson 1987; Grice 1975) and its focus on professional and academic genres started in the 90s with the work of Swales (1990) or Bhatia (1993), it is in the last two decades when intercultural rhetoric has become one of the priorities of applied linguistics and translation studies (Connor et al. 2008).

Over the last twenty years significant research has been published on the description and contrastive analysis of the culture-specific pragmalinguistic conventions ruling speech acts, social interaction, and discourse strategies across languages (e.g. Blum-Kulka et al. 1989; Díaz-Pérez 2003; Márquez-Reiter 2000; Wierzbicka 1991). However, according to some specialists (e.g. Clyne 1994; García-Yeste 2013; Giménez-Moreno and Skorczynska 2013; Guillén-Nieto 2013; Ivorra-Pérez 2012, 2015; Kaplan 1966), these previous studies do not explain why the main principles of interaction are influenced and motivated by certain cultural values. For example, Kaplan (1966), and later on Clyne (1994), observed that the differences in the rhetorical patterns of texts across cultures are more likely to reflect specific cultural and educational training factors which help shape the writing conventions learned in a culture.

The above observations leaded some specialists to adopt more interdisciplinary approaches which included insights from anthropologists and social psychologists like Hall (1976) and Hofstede (1991). In the light of these studies, various cultural dimensions have been compared between English and Spanish in different professional and academic genres such as opinion essays, business websites, press advertising or business letters (e.g. García-Yeste 2013; Guillén-Nieto 2013; Ivorra-Pérez 2012,2014, 2015) and on the way speech acts are performed in British or American English in comparison with other languages like Russian or Ukrainian (e.g. Loukianenko-Wolfe 2008; Prykarpatska 2008). All these studies yield important differences in communication styles between languages, which mainly obey to reasons of culture.

As regards the influence of cultural values on metadiscourse, the works of Guillén-Nieto (2013) on the influence of cultural values on the use of interactional metadiscourse patterns in the business letter of introduction in Peninsular-Spanish and British toy companies as well as Ivorra-Pérez $(2014,2015)$ on the impact of culture on the use of interactional metadiscourse in Peninsular-Spanish, British-English and American-English business websites stand out. The findings of these works reveal interesting differences and show how some of Hofstede's cultural dimensions influence the way interpersonality is produced and interpreted in different languages.

As for movie reviews, the role of interacional metadiscourse has also been investigated in different languages and cultures. Drawing on Hyland and Tse's (2004) metadiscourse 
model, Zuo (2011) and Zhang (2013) analyse the presence of interactive and interactional metadiscourse on English film reviews. It also deserves special attention the research of Carretero (2014) on the role of authorial voice in Peninsular-Spanish and English reviews of films, half professional and half consumer-generated. This linguist obtains remarkable differences between both kinds of reviews in these two societies as far as engagement markers are concerned.

Despite the importance of the aforementioned studies, there seems to be a loophole in the literature as the impact of cultural values on the way interpersonality is expressed in Peninsular-Spanish and British-English movie reviews has not been dealt with yet.

\section{THE STUDY}

\subsection{Research questions}

In this paper, we attempt to answer the following research questions:

a) What is the Spaniards' and Britons' degree of contextual dependence (Hall 1976) and individualistic index (Hofstede 1991) on the interactional metadiscourse strategies included in Peninsular-Spanish and British-English online movie reviews?

b) What are the similarities and differences that interactional metadiscourse strategies show in Peninsular-Spanish and British-English online movie reviews?

c) Is there any potential difficulty or difference that these interactional markers can generate in the transfer between both languages by L2 learners?

\subsection{Sample}

Our study was carried out from March to September 2014 among a selected sample of film reviews retrieved from Internet websites of quality newspapers such as El País and The Guardian. These are considered two online acclaim newspapers in Spain and Great Britain, respectively.

We chose this text type because it is currently one of the most widely read genre reaching a relatively heterogeneous audience, specially movie-going people. Additionally, the conventions of this genre have been very influential and have been used as text models for teaching L2 writing skills.

82 movie reviews (41 in Peninsular Spanish and 41 in British English) were selected. These covered various genres like drama, comedy, science fiction, horror, among others. These texts address a broad audience and treat the reviews with sufficient plurality to allow for cross-linguistic comparison. The reviews chosen were written by different reviewers so as to avoid a possible bias in the results due to individual and personal stylistic preferences. The total number of words for both corpora is 33,550 (British English: 17,995 words - Peninsular Spanish: 15,555 words). 


\subsection{Sample analysis}

A first stage consisted in observing and classifying the most relevant markers of interactional metadiscourse categories found in both data sets. Although different taxonomies have been proposed so far (e.g. Crismore 1989; Hyland 1998; Mauranen 1993; Vande-Kopple 1985), we followed Hyland and Tse's (2004) taxonomy, as this has been very influential in studies researching the use of metadiscourse across languages and cultures: hedges, boosters, attitude, engagement and self-mention markers. We aimed to find out which interactional metadiscourse markers prevailed in Peninsular-Spanish and which in British-English film reviews while discovering which linguistic categories were used to perform a particular rhetorical function. Our analysis also went beyond the interactional model of Hyland and Tse (2004), as other interactional categories like references to a third person in discourse and depersonalisation strategies were also analysed.

A quantitative analysis was carried out with the help of the computer program Textworks 1.0 (Gil et al. 2004) in order to count the absolute and relative frequency of the linguistic categories through which interactional metadiscourse markers are expressed in the corpora analysed. The absolute frequency correlates with the total amount of occurrences of a particular linguistic category and the relative frequency results from dividing the absolute frequency by the total amount of words contained in each corpus. As both corpora were inevitably of unequal size (Peninsular-Spanish corpus: 15,555 words and British-English corpus: 17,995 words), the absolute frequency was computed per 1,000 words, which is a conventional way of standardising results of corpora of different sizes.

The results were submitted to statistical analysis through the chi-square test of homogeneity in a contingency table by means of SPSS Statistics Software 22. The chi-square test is a non-parametric test used to compare frequencies in studies dealing with data measurable with nominal scales. When the statistical difference between both corpora was equal to or below $\mathrm{p}<.05$, this was interpreted as significant. If it was below $\mathrm{p}<.01$, the statistical difference was rendered as highly significant.

\section{RESULTS}

\subsection{General results}

In this section we describe our most relevant findings and illustrate these through different extracts drawn from the corpora analysed.

\subsubsection{Hedges}

Hedges are rhetorical devices used for "blurring the speaker's commitment to the truth of the proposition conveyed" (Prince et al. 1982). For the current study the following categories of hedges were selected: approximators (e.g. roughly, somewhat, often, sort of, a bit of, etc./ aproximadamente, algo, con frecuencia, una clase de, un poco de, etc.); modal verbs (e.g. can, could, may, might, will, would, etc./puede, podría, podia, etc.) along with Spanish conditional verbs ending with suffix -ía (e.g. parecería, sería, etc.); semi-auxiliary 
verbs (e.g. appear to, seem to, looks as if, etc./parece ser, parece como si, al parecer, etc.); if conditionals; and probability adverbs, adjectives and nouns (e.g. probably, likely, possible, likelihood, feasible, plausible, apparently, etc./probablemente, es posible, aparentemente, etc.). The results in the use of hedges are shown in table 1 below:

\begin{tabular}{|c|c|c|c|c|c|}
\hline $\begin{array}{c}\text { Interactional } \\
\text { metadiscourse } \\
\text { strategies }\end{array}$ & \multicolumn{2}{|c|}{$\begin{array}{c}\text { PenSp movie re- } \\
\text { views Total words } \\
15,555\end{array}$} & \multicolumn{2}{|c|}{$\begin{array}{l}\text { BrE movie reviews } \\
\text { Total words } 17,995\end{array}$} & $\begin{array}{c}\text { Chi-square } \\
\text { test } X^{2} \text { Pen- } \\
\text { Sp-BrE }\end{array}$ \\
\hline Hedges & $\begin{array}{l}\mathrm{AF}^{1} \\
130\end{array}$ & $\begin{array}{l}\mathrm{RF}^{2} \\
\text { (x 1,000 } \\
\text { words) } 8.35\end{array}$ & $\begin{array}{l}\mathrm{AF} \\
257\end{array}$ & $\begin{array}{l}\text { RF } \\
\text { (x 1,000 } \\
\text { words) } \\
14.28\end{array}$ & $\begin{array}{l}51.676 \\
(.000)^{* * *}\end{array}$ \\
\hline Approximators & 42 & 2.70 & 95 & 5.27 & $\begin{array}{l}22.011 \\
(.000)^{* * *}\end{array}$ \\
\hline Modal verbs & 28 & 1.80 & 64 & 3.55 & $\begin{array}{l}14.766 \\
(.000)^{* * *}\end{array}$ \\
\hline $\begin{array}{l}\text { Semi-auxiliary } \\
\text { verbs }\end{array}$ & 26 & 1.67 & 55 & 3.05 & $\begin{array}{l}10.821 \\
(.000)^{* * *}\end{array}$ \\
\hline If conditionals & 7 & 0.45 & 12 & 0.66 & $\begin{array}{l}1.328 \\
(.249)\end{array}$ \\
\hline $\begin{array}{l}\text { Probability nouns, } \\
\text { adjectives } \\
\text { and adverbs }\end{array}$ & 27 & 1.73 & 31 & 1.72 & $2.84(.594)$ \\
\hline
\end{tabular}

1 AF stands for "absolute frequency"

2 RF stands for "relative frequency"

Table 1: Hedges. Frequencies obtained for the PenSp and BrE corpora $\left({ }^{*} p=.05 ; * * p<.05 ; * * * p<.01\right)$.

As can be observed in Table 1, the occurrence of hedges exhibits different findings for both corpora. In general, the BrE corpus (257/14.28) reaches higher frequencies than its PenSp counterpart (130/8.35), revealing highly significant statistical differences between both data sets $\left(\mathrm{x}^{2}=51.676, \mathrm{p}=.000\right)$. This is relevant in the use of approximators, modals and semi-auxiliary verbs. As regards if conditionals and probability adjectives, nouns and adverbs, the frequency slightly increases in the BrE corpus, but no statistical difference has been found with respect to the PenSp data set.

These findings suggest that British writers employ a higher number of hedged expressions to minimise their opinions on the film reviewed, which may allow the reader to disagree to different degrees and leave room for alternative points of view. On the contrary, 
Peninsular-Spanish writers favour a lesser frequency of these markers and their opinions look as if they were more overtly expressed.

To illustrate our results, we provide some examples from the corpora analysed. The first two extracts are drawn from the BrE corpus and the second two from the PenSp one:

As shown in example (1), hedged expressions such as a probability adjective (apparent) and a semi-auxiliary verb (seems to) soften the writer's opinion regarding the way the director has made the movie:

[...] most of 'Labor Day's' problems stem from an apparent (probability adjective) excessive amour for his source material. He seems to (semi-auxiliary verb) think that he has Flaubert on his hands, when what he has is "The Bridges of Madison County".

(http://www.theguardian.com/film/2014/jan/31/labor-day-review-winslet-brolin-pie)

In example (2) we appreciate the use of a modal verb (may) to play down the writer's viewpoint on the role played by actor George Clooney:

Part of Clooney's difficulty may (modal verb) well be the sheer size of the operation he is attempting to render in cinematic form [...].

(http://www.theguardian.com/film/2014/feb/08/monuments-men-review-george-clooney-berlin).

Clear differences can be observed in examples (3) and (4) below. As regards example 3 , the writer's view on the content, the characters, the tone and the visualisation of the movie is conveyed by means of on-record linguistic strategies like negative adjectives (farragosa, ridiculos, melifluo, pedestre), adverbs used as intensifiers (sorprendentemente) and quantifier adjectives (enorme):

(3)

En esta fantasía pseudo-religiosa, con mucho de ideología 'new age' y abundantes dosis de azúcar, la narración es farragosa, los personajes, ridículos; el tono, melifluo, y la visualización sorprendentemente pedestre [....], [...] 'Cuento de invierno' es un enorme fracaso. [In this pseudo-religious fantasy, with too much 'new age' ideology and sugar dose, the narration is dense, the characters are ridiculous, the tone is sickly-sweet, and the visualization is surprisingly pedestrian. 'A New York Winter's Tale' is an enormous failure $]^{87}$

(http:/cultura.elpais.com/cultura/2014/02/13/actualidad/1392300296_731844.html)

Example (4) includes similar features as those described in the previous example. The reviewer comments on the particular style that defines the director of the film and uses an on-record quantifying adjective (desmesurada) as well as a quantifying adverb (mиу) followed by adjectives (personal, distinto, transgresor). Nevertheless, these strategies are never minimised by means of hedged expressions:

87 The translations into English of the Peninsular-Spanish extracts are ours. 
(4)

Es un director con desmesurada voluntad de estilo, de originalidad, de contar historias desde un punto de vista muy personal, distinto, transgresor [...].[He is a director with an enormously style will and originality, who tells stories from a very personal, distinctive, and transgressor point of view].

(http://cultura.elpais.com/cultura/2014/01/30/actualidad/1391114752_063766.html)

\subsubsection{Boosters}

In sharp contrast with hedges, boosters "imply certainty and emphasise the force of propositions" (Hyland and Tse 2004: 168). In this study the following categories of boosters were selected: intensifying adjectives (e.g. enormous, excessive, barnstorming/enorme, excesivo, arrollador/a, etc.); emphatic expressions (e.g. in fact, it is clear that, indeed, for sure, etc./de hecho, está claro que, seguro que, etc.); superlative adjectives (e.g. the most important, the greatest, the best, etc./el más importante, el más grande, el mejor, etc.); amplifying adverbs (e.g. even, completely, totally, undoubtedly, etc./incluso, completamente, totalmente, indudablemente, etc.); and emphatic adverbs (e.g. actually, really, certainly, literally, etc./ciertamente, realmente, literalmente). Table 2 shows the frequency of occurrence of boosters on PenSp and BrE data sets:

\begin{tabular}{|c|c|c|c|c|c|}
\hline $\begin{array}{l}\text { Interactional } \\
\text { metadiscourse } \\
\text { strategies }\end{array}$ & \multicolumn{2}{|c|}{$\begin{array}{c}\text { PenSp movie re- } \\
\text { views Total words } \\
15,555\end{array}$} & \multicolumn{2}{|c|}{$\begin{array}{c}\text { BrE movie reviews Total } \\
\text { words } 17,995\end{array}$} & $\begin{array}{c}\text { Chi-square } \\
\text { test } X^{2} \text { Pen- } \\
\text { Sp-BrE }\end{array}$ \\
\hline Boosters & $\begin{array}{l}\text { AF } \\
243\end{array}$ & $\begin{array}{l}\text { RF } \\
\text { (x 1,000 } \\
\text { words) } \\
15.62\end{array}$ & $\begin{array}{l}\text { AF } \\
257\end{array}$ & $\begin{array}{l}\text { RF } \\
(\mathrm{x} \\
1,000 \text { words }) \\
14.28\end{array}$ & $\begin{array}{l}.904 \\
(.342)\end{array}$ \\
\hline $\begin{array}{l}\text { Intensifying } \\
\text { adjectives }\end{array}$ & 85 & 5.46 & 54 & 3.00 & $\begin{array}{l}7.430 \\
(.006) * * *\end{array}$ \\
\hline $\begin{array}{l}\text { Emphatic ex- } \\
\text { pressions }\end{array}$ & 8 & 0.51 & 12 & 0.66 & $\begin{array}{l}.808 \\
(.369)\end{array}$ \\
\hline $\begin{array}{l}\text { Superlative } \\
\text { adjectives }\end{array}$ & 47 & 3.02 & 32 & 1.77 & $\begin{array}{l}2.965 \\
(.085)\end{array}$ \\
\hline $\begin{array}{l}\text { Amplifying } \\
\text { adverbs }\end{array}$ & 87 & 5.59 & 109 & 6.05 & $\begin{array}{l}2.738 \\
(.098)\end{array}$ \\
\hline $\begin{array}{l}\text { Emphatic ad- } \\
\text { verbs }\end{array}$ & 16 & 1.02 & 18 & 1.00 & $.120(.729)$ \\
\hline
\end{tabular}

Table 2: Boosters. Frequencies obtained for the PenSp and BrE corpora $\left({ }^{*} p=.05 ; * * p<.05 ; * * * p<.01\right)$. 
Generally speaking, one can find a small difference in the frequency of boosters in each corpus. Nonetheless, the number of occurrences included in the PenSp reviews slightly increases. When looking at the statistical differences between both data sets, these are not significant either (PenSp: 243/15.62-BrE: 225/12.50; $\mathrm{x}^{2}=.904, \mathrm{p}=.342$ ).

By contrast, a closer look at each of the linguistic categories reveals some significant findings. While the occurrence of intensifying adjectives and superlatives is higher in the PenSp movie reviews, their BrE counterparts increase the frequency in the use of emphatic expressions, amplifying and emphatic adverbs. Despite this, the results of the chi-square test do not yield statistical differences. The results obtained indicate that boosters are similarly used in PenSp and BrE movie reviews, although intensifying adjectives abound in the former with statistical differences with respect to the latter (PenSp: 85/5.46-BrE: $\left.54 / 3.00 ; \mathrm{x}^{2}=7.430, \mathrm{p}=.006\right)$.

Some examples from the corpora analysed are worth observing. The first two extracts are taken from the PenSp data set and the second two correspond to the BrE data set:

In example (5) the intensifying adjective (soberbia) is used by the writer to describe one of the scenes contained in the movie:

(5)

[...] la escena del atraco al restaurante es una soberbia (instensifying adjective) prueba de fuerza estilística [...]. [the restaurant robbery scene is an arrogant test of stylistic force].

(http://cultura.elpais.com/cultura/2013/03/14/actualidad/1363283318_270620.html)

The use of the amplifying adverb (profundamente) in example (6) is another type of booster by means of which the force of the reviewer's opinion is emphasised, particularly when he addresses the director of the film:

(6)

[...] Y luego, existe otro Ozón profundamente (amplifying adverb) retorcido y morboso en el planteamiento y desarrollo de intrigas sociales [...]. [And then there is another Ozón deeply twisted and ghoulish in the approach and development of social intrigue].

(http://cultura.elpais.com/cultura/2014/03/06/actualidad/1394135642_610116.html)

In order to highlight the performance of one of the characters of the film, the writer resorts to the use of an intensifying adjective (barnstorming) in example

(7)

Its politics appear conservative, but this Reagan-era story of a heterosexual 'good ol' boy' who imports and sells Aids therapies has a barnstorming (intensifying adjective) performance from Matthew McConaughey [...].

(http://www.theguardian.com/film/2014/feb/06/dallas-buyers-club-review)

The intensifying adjective (superlative) along with the amplifying adverb (entirely) are also used by the writer in example (8). Both strategies emphasise the role played by the actress Cate Blanchet in the movie: 
(8)

[...] Cate Blanchet, on the other hand, is badly served with a thin role and saddled with a terrible accent as a Parisian curator-cum-resistance operative, and this normally superlative (intensifying adjective) performer is entirely (amplifying adverb) wasted [...].

(http://www.theguardian.com/film/2014/feb/08/monuments-men-review-george-clooney-berlin)

\subsubsection{Attitude markers}

Attitude markers, also called "expressive markers" (Dafouz-Milne 2006: 71), represent a personal appraisal of the content of the text. These are used by writers to provide their own personal and subjective opinion about what they state. Eight different linguistic categories of attitude markers have been chosen: attitude adjectives (e.g. strange, surprising, useful, splendid, etc./extraño, soprendente, eficaz, espléndido, etc.); attitude adverbs (e.g. fortunately, obviously, surprisingly, etc./afortunadamente, obviamente, sorprendentemente, etc.); attitude nouns (e.g. oddness, beauty, usefulness/lo extraño, la belleza, la eficacia, etc.) attitude verbs (e.g. say, feel, think, suppose, want, realise, understand, etc./ decir, estimar, creer, suponer, querer, darse cuenta, entender, etc.); deontic verbs (e.g. should, have to, need, must/debería, tener que, necesitar, deber, etc.); comparatives (e.g. $\mathrm{X}$ is better than $\mathrm{Y} / \mathrm{X}$ es mejor que Y); and exclamations (e.g. It is marvelous written!/¡Está maravillosamente escrito!). The frequency of occurrence of attitude markers in both corpora is given in table 3 :

\begin{tabular}{|l|l|l|l|l|l|}
\hline $\begin{array}{c}\text { Interactional } \\
\text { metadiscourse } \\
\text { strategies }\end{array}$ & \multicolumn{2}{|c|}{$\begin{array}{c}\text { PenSp movie reviews } \\
\text { Total words 15,555 }\end{array}$} & \multicolumn{2}{|c|}{$\begin{array}{c}\text { BrE movie reviews } \\
\text { Total words 17,995 }\end{array}$} & $\begin{array}{c}\text { Chi-square } \\
\text { test X2 Pen- } \\
\text { Sp-BrE }\end{array}$ \\
\hline Attitude markers & $\begin{array}{l}\text { AF } \\
1,582\end{array}$ & $\begin{array}{l}\text { RF (x } \\
1,000 \text { words }) \\
101.70\end{array}$ & $\begin{array}{l}\text { AF } \\
1,573\end{array}$ & $\begin{array}{l}\text { RF (x } \\
1,000 \text { words) } \\
87.41\end{array}$ & $.122(.727)$ \\
\hline Attitude adjectives & 839 & 53.93 & 960 & 53.34 & $\begin{array}{l}80.979 \\
(.000)^{* * *}\end{array}$ \\
\hline Attitude adverbs & 46 & 2.95 & 157 & 8.72 & $\begin{array}{l}67.551 \\
(.000)^{* * *}\end{array}$ \\
\hline Attitude nouns & 621 & 39.92 & 317 & 17.61 & $\begin{array}{l}185.545 \\
(.000)^{* * *}\end{array}$ \\
\hline Attitude verbs & 11 & 0.70 & 25 & 1.38 & $\begin{array}{l}5.544 \\
(.019)^{* * * *}\end{array}$ \\
\hline Deontic verbs & 6 & 0.38 & 11 & 0.61 & $\begin{array}{l}1.483 \\
(.223)\end{array}$ \\
\hline Comparatives & 55 & 3.53 & 95 & 5.27 & $\begin{array}{l}11.532 \\
(.0001)^{* * *}\end{array}$ \\
\hline Exclamations & 4 & 0.25 & 8 & 0.44 & $\begin{array}{l}1.341 \\
(.247)\end{array}$ \\
\hline
\end{tabular}

Table 3: Attitude markers. Frequencies for the PenSp and BrE corpora $\left({ }^{*} p=.05 ; * *<<.05 ; * * * p .01\right)$. 
The total number of occurrences in the use of attitude markers does not yield important differences in each corpus although it is slightly higher in the PenSp one. In this sense, no significant statistical differences have been found $\left(\mathrm{x}^{2}=.122, \mathrm{p}=.727\right)$. Yet, the findings obtained in each linguistic category unveil that the PenSp corpus obtains higher frequencies in the use of attitude nouns. On the contrary, attitude adjectives, attitude adverbs, comparatives and attitude verbs show higher frequencies in the $\mathrm{BrE}$ data set. These exhibit highly significant as well as significant statistical differences between both corpora. The few instances found in relation to both exclamations and deontic verbs in each corpus show no significant statistical differences.

The above findings could support the idea that British writers are more interested than their Peninsular-Spanish counterparts in including a wider range of attitude markers when they review movies. Different examples from the corpora analysed can shed light on our results. Examples (9) and (10) are representative examples of BrE movie reviews:

In example (9) the writer makes use of attitude adjectives (hacksaw-sharp, inappropriate) together with combinations of attitude adverbs + attitude adjectives (witheringly bleak, bitterly acerbic, pointedly cruel) to express a personal view on the movie:

(9)

[...] The hacksaw-sharp (attitude adjective) result, which mixes winces with inappropriate (attitude adjective) laughter, is witheringly bleak (attitude adverb + attitude adjective), bitterly acerbic (attitude adverb + attitude adjective), and pointedly cruel (attitude adverb + attitude adjective). (http://www.theguardian.com/film/2013/dec/08/big-bad-wolves-film-review)

As shown in example (10), comparative forms (more conventional confection than) are used to contrast this film with others previously made by the same director. Aside from that, we also find a combination of attitude adverb + attitude adjective (vividly impressive):

[...] In some ways, Seven Psychopaths is a more conventional confection than (comparison) its predecessor $[\ldots],[\ldots]$ and it suffers some of the same short-burn as a Tarantino flick, vividly impressive (attitude adverb + attitude adjective) at the time, but all fireworks [...].

(http://www.theguardian.com/film/2012/sep/07/seven-psychopaths-review)

Examples (11) and (12) are drawn from the PenSp data set. In example (11), we observe an attitude adjective (fenomenal) and an attitude noun (complejidad), which are also used by the writer to express a personal evaluation on the movie:

(11)

[...] Don Jon arranca fenomenal (attitude adjective) en su primera mitad, pero acaba faltándole complejidad (attitude noun) para que su reflexión sobre el sexo [...].[Don Jon starts greatly in its first half, but it lacks complexity so that its thoughts on sex ...].

(http://cultura.elpais.com/cultura/2013/10/31/actualidad/1383236144_787890.html) 
Comparative forms (más clásico, menos distintivo, más olvidable) are also used by the PenSp writer in example (12) to provide a personal and subjective appreciation on the way Mike Newell has directed the movie:

(12)

El británico Mike Newell parece haber optado por un camino más clásico (comparison), pero su resultado es menos distintivo (comparison) y, por tanto, más olvidable (comparison). [The British Mike Newell seems to have chosen a more classical path, but whose result is less distinctive and so more forgettable].

(http://cultura.elpais.com/cultura/2013/03/26/actualidad/1364319429_751330.html)

\subsubsection{Engagement markers}

Engagement markers have a relevant interpersonal function since "they build an explicit relationship with readers" (Hyland 2004: 169). For this analysis the following categories of engagement markers have been chosen: second-person references (e.g. you/tú/vosotros/ as,usted/es); rhetorical questions (e.g. How many ways can a movie fail?/¿de cuántas maneras puede fracasar una película?); imperatives (e.g. Watch it!, you won’t regret!/iVayan a verla, no se arrepentirán!). As Spanish is a pro-drop language, we have also analysed verbs ending in second-person singular and plural forms (e.g. encontrarás, encontraréis).

We have also included in the analysis references to a third person in discourse (e.g. but for the viewer well acquainted .../ pero para el espectador bien familiarizado ...); generic use of second-person forms (e.g. Whether you buy what follows .../Si compras lo que sigue ...); or indefinite pronouns (e.g. one can think that the movie .../uno puede pensar que la película...). In our view, these can also be considered engagement markers although implicitly expressed. Table 4 shows the frequency of occurrence of these categories of engagement markers on the movie reviews selected for the corpora:

\begin{tabular}{|l|l|l|l|l|l|}
\hline $\begin{array}{c}\text { Interactional metadis- } \\
\text { course strategies }\end{array}$ & \multicolumn{2}{|c|}{$\begin{array}{c}\text { PenSp movie } \\
\text { reviews Total } \\
\text { words 15,555 }\end{array}$} & \multicolumn{2}{|c|}{$\begin{array}{c}\text { BrE movie } \\
\text { reviews Total } \\
\text { words 17,995 }\end{array}$} & $\begin{array}{c}\text { 15i-square } \\
\text { test X Pen- } \\
\text { Sp-BrE }\end{array}$ \\
\hline $\begin{array}{l}\text { Explicit engagement } \\
\text { markers }\end{array}$ & $\begin{array}{l}\mathrm{AF} \\
25\end{array}$ & $\begin{array}{l}\mathrm{RF}(\mathrm{x} \\
1,000 \\
\text { words }) \\
1.60\end{array}$ & $\begin{array}{l}\mathrm{AF} \\
29\end{array}$ & $\begin{array}{l}\mathrm{RF}(\mathrm{x} \\
1,000 \\
\text { words }) \\
1.61\end{array}$ & $\begin{array}{l}.305 \\
(.581)\end{array}$ \\
\hline Second person references & 9 & 0.57 & 8 & 0.44 & $\begin{array}{l}.059 \\
(.808)\end{array}$ \\
\hline Rhetorical questions & 12 & 0.77 & 18 & 1.00 & $\begin{array}{l}1.218 \\
(.270)\end{array}$ \\
\hline Imperatives & 4 & 0.25 & 3 & 0.16 & $\begin{array}{l}.143 \\
(.705)\end{array}$ \\
\hline
\end{tabular}




\begin{tabular}{|l|l|l|l|l|l|}
\hline $\begin{array}{c}\text { Interactional metadis- } \\
\text { course strategies }\end{array}$ & \multicolumn{2}{|c|}{$\begin{array}{c}\text { PenSp movie } \\
\text { reviews Total } \\
\text { words 15,555 }\end{array}$} & \multicolumn{2}{|c|}{$\begin{array}{c}\text { BrE movie } \\
\text { reviews Total } \\
\text { words 17,995 }\end{array}$} & $\begin{array}{c}\text { Chi-square } \\
\text { test X2 Pen- } \\
\text { Sp-BrE }\end{array}$ \\
\hline $\begin{array}{l}\text { Implicit engagement } \\
\text { markers }\end{array}$ & 84 & 5.40 & 58 & 3.22 & $\begin{array}{l}5.124 \\
(.024)^{* *}\end{array}$ \\
\hline $\begin{array}{l}\text { Reference to a third per- } \\
\text { son }\end{array}$ & 68 & 4.37 & 20 & 1.11 & $\begin{array}{l}27.387 \\
(.000)^{* * *}\end{array}$ \\
\hline $\begin{array}{l}\text { Generic use of second } \\
\text { person reference }\end{array}$ & 8 & 0.51 & 23 & 1.27 & $\begin{array}{l}7.372 \\
(.007)^{* * *}\end{array}$ \\
\hline Indefinite pronouns & 8 & 0.51 & 15 & 0.83 & $\begin{array}{l}2.155 \\
(.142)\end{array}$ \\
\hline
\end{tabular}

Table 4: Engagement markers. Frequencies for the PenSp and BrE corpora $(* p=.05 ; * *<<.05$; $* * * \mathrm{p}<.01)$.

As for the use of explicit engagement markers, the results display low frequencies and no significant statistical differences have been found. This may mean that engagement markers are not prototypical of this professional genre. Notwithstanding these results, the frequency in the use of implicit engagement markers indicates significant differences between both languages. The PenSp corpus shows a higher frequency in the use of these markers with significant statistical differences with respect to BrE one (PenSp: 84/5.40BrE: 58/3.22; $\left.x^{2}=5.124, p=.024\right)$.

A deeper analysis reveals that while the frequencies for a third person in discourse are higher in PenSp movie reviews (PenSp: 68/4.3-BrE: 20/1.11; $\mathrm{x}^{2}=27.387, \mathrm{p}=.000$ ), their BrE counterparts present a higher occurrence of generic second-person references (PenSp: 8/0.51-BrE: 23/1.27, $\mathrm{x}^{2}=7.372$, $\mathrm{p}=.007$ ). Although the $\mathrm{BrE}$ movie reviews include a higher number of occurrences of indefinite pronouns, the statistical differences observed in relation to the PenSp corpus are not significant (PenSp: 8/0.51-BrE: $15 / 0.8, \mathrm{x}^{2}=2.155$, $\mathrm{p}=.142$ ). To illustrate our findings, the first two examples below are drawn from the PenSp corpus and the second two from the BrE one. In all of them, we can observe references to a third person, generic use of second-person references and indefinite pronouns:

In example (13) the writer makes reference to a third person (el espectador) in order to avoid addressing the reader directly when he is commenting the effect that the movie may have on viewers:

[...] "Se supone que esta intriga puede generar tensión y que el espectador (reference to a third person) se implique en un universo tan turbio y presuntamente abarrotado de matices [...]. [It is supposed that this intrigue may create tension and the spectator may be involved in such a muddy universe, which is presumably crammed with nuances].

(http://cultura.elpais.com/cultura/2014/01/30/actualidad/1391114752_063766.html) 
Similarly, in example (14) the writer includes generic second-person references (entiendes, te) so as not to address the reader in a direct way:

[...] Y entiendes (generic use of second-person reference) que practicar en la adolescencia profesión tan dura y arriesgada puede estar regida por la explotación, la supervivencia, la codicia, o la inaplazable necesidad de dinero [...], [...] El guión te (generic use of second-person reference) puede desconcertar, pero observar a esa mujer otorga un placer transparente. [And you understand that practicing such a hard and risky profession in her teens can be governed by exploitation, survival, greed, or the necessity for money, which cannot be put off; The script can disconcert you but observing that woman provides a transparent pleasure].

(http://cultura.elpais.com/cultura/2014/03/06/actualidad/1394135642_610116.html)

Third person references (some viewers, some) are also used by the writer to implicitly address potential viewers of the movie in example (15):

[...] This is a film guaranteed some viewers (reference to a third person) the way garlic affected Bela Lugosi. Some (reference to a third person) will find it unbearably arch and the lovers rebarbatively self-satisfied and above it all [...].

(http://www.theguardian.com/film/2014/feb/23/only-lovers-left-alive-review)

In a similar vein, a generic use of second-person reference (you) so as not to address readers explicitly is observed in example (16):

[...] Newell's film pulls off that rarest of tricks: by illuminating the book in such a harsh light, you (generic use of second-person reference) come away thinking the less of it [...].

(http://www.theguardian.com/film/2012/sep/11/great-expectations-review)

\subsubsection{Self-mention markers}

Self-mention markers are "used to refer to the writer of a text in an explicit way" (Hyland 2004: 169). In this analysis the following categories have been selected: first-person singular and plural pronouns (e.g. I, me, my, mine, we, us, our, etc./yo, mi, mío, nosotros, nuestro etc.). For the PenSp corpus, we have also analysed verbs ending in first-singular and plural forms (e.g. Pienso que .../Descubrimos que ...).

Special attention has been paid to depersonalisation strategies, which are also very recurrent in the corpora analysed. These cover personifications (e.g. DreamWorks' latest offers a fairly consistent .../lo ultimo de DreamWorks ofrece una ligera consistencia ...), agentless passive sentences (e.g. The idea of safe sex for people is not discussed/La idea del sexo seguro no se trata ...), impersonal passives (e.g. It is generally thought to have been launched in 1966 .../Por lo general, se piensa que ha sido lanzada en 1966 ...), nominalised sentences (e.g. The result is less distinctive .../El resultado es menos distintivo ...) and impersonal expressions followed by infinitive forms (e.g. It is a pleasure to see Ian 
Mckellen back in the cloak ... /es un placer ver a Ian Mckellen en la capa de nuevo...). Table 5 summarises the main results found in relation to self-mention markers in both corpora:

\begin{tabular}{|c|c|c|c|c|c|}
\hline $\begin{array}{l}\text { Interactional meta- } \\
\text { discourse strategies }\end{array}$ & \multicolumn{2}{|c|}{$\begin{array}{c}\text { PenSp movie re- } \\
\text { views Total words } \\
15,555\end{array}$} & \multicolumn{2}{|c|}{$\begin{array}{l}\text { BrE movie reviews } \\
\text { Total words } 17,995\end{array}$} & $\begin{array}{c}\text { Chi- } \\
\text { square test } \\
\mathrm{X}^{2} \text { PenSp- } \\
\text { BrF }\end{array}$ \\
\hline Self-mention markers & $\begin{array}{l}\mathrm{AF} \\
70\end{array}$ & $\begin{array}{l}\mathrm{RF}(\mathrm{x} 1,000 \\
\text { words) } \\
4.50\end{array}$ & $\begin{array}{l}\text { AF } \\
76\end{array}$ & $\begin{array}{l}\mathrm{RF}(\mathrm{x} 1,000 \\
\text { words) } \\
4.22\end{array}$ & $\begin{array}{l}.266 \\
(.606)\end{array}$ \\
\hline $\begin{array}{l}\text { First-person } \\
\text { singular forms }\end{array}$ & 37 & 2.3 & 37 & 2.05 & $\begin{array}{l}.000 \\
(.1000)\end{array}$ \\
\hline $\begin{array}{l}\text { First-person } \\
\text { plural forms }\end{array}$ & 33 & 2.12 & 39 & 2.16 & $\begin{array}{l}.519 \\
(.471) \\
\end{array}$ \\
\hline $\begin{array}{l}\text { Depersonalisation } \\
\text { strategies }\end{array}$ & 349 & 22.43 & 273 & 15.17 & $\begin{array}{l}13.478 \\
(.000)^{* * *}\end{array}$ \\
\hline Personifications & 206 & 13.24 & 120 & 6.66 & $\begin{array}{l}27.105 \\
(.000)^{* *}\end{array}$ \\
\hline $\begin{array}{l}\text { Agentless } \\
\text { passive sentences }\end{array}$ & 65 & 4.17 & 109 & 6.05 & $\begin{array}{l}12.187 \\
(.000)^{* * *}\end{array}$ \\
\hline $\begin{array}{l}\text { Impersonal } \\
\text { passive sentences }\end{array}$ & 19 & 1.22 & 7 & 0.38 & $\begin{array}{l}5.611 \\
(.018) * *\end{array}$ \\
\hline $\begin{array}{l}\text { Impersonal expres- } \\
\text { sions+infinitive forms }\end{array}$ & 42 & 2.70 & 31 & 1.72 & $\begin{array}{l}1.720 \\
(.190)\end{array}$ \\
\hline
\end{tabular}

Table 5: Self-mention markers. Frequencies for the PenSp and BrE corpora $\left({ }^{*} p=.05 ; * * p<.05\right.$; $* * * p<.01)$.

The results obtained in the use of self-mention markers do not show significant statistical differences between both corpora $\left(x^{2}=.266, p=.606\right)$. It is relevant to observe how both PenSp and BrE movie reviews resort to the same number of occurrences in the use first-person singular forms although the frequency is low. Regarding plural forms, the BrE corpus slightly increases its use, but no significant statistical differences have been found with respect to its PenSp counterpart $\left(\mathrm{x}^{2}=.519, \mathrm{p}=.471\right)$.

As far as depersonalisation strategies are concerned, the PenSp corpus shows a higher frequency of these markers (349/22.43) than the BrE one (273/15.17) with highly significant statistical differences $\left(\mathrm{x}^{2}=13.478, \mathrm{p}=.000\right)$. More particularly, the frequency of personifications, impersonal passive sentences and nominalised sentences stand out, showing significant statistical differences with respect to the BrE corpus. As for the use of agentless passive sentences, the frequency increases in the $\mathrm{BrE}$ data set with significant statistical differences 
too. As regards impersonal expressions in combination with infinitive forms, PenSp movie reviews obtain higher frequencies. Despite this, the statistical differences obtained with respect to the BrE data set are not significant.

Different extracts from both corpora can be considered relevant examples to illustrate our findings. In example (18) the PenSp writer makes use of personifications and in example (19) he resorts to the use of an agentless passive sentence. Both linguistic categories are used to hide the writers' voice when they give their viewpoint on the way the director has made the movie:

[...] La película busca (personification) equivalentes corpóreos al esquematismo gráfico del modelo, respeta la esencia de sus personajes, sólo atenúa (personification) un par de grados el mordiente humor marca Ward [...]. [The movie seeks corporeal equivalents to the graphic scheme of the model, respects the essence of its characters, it only tones down a pair of grades the bating humor of the Ward brand].

(http://cultura.elpais.com/cultura/2014/03/06/actualidad/1394129796_069459.html)

[...] Comedia dramática de libro, pues ambos aspectos, la comedia y el drama, se presentan (agentless passive sentence) de forma alternativa, sin cruzarse, sin unirse en una misma secuencia $[\ldots]$..[Book of dramatic comedy, since both, comedy and drama, are presented alternatively, without crossing themselves, without joining in a same sequence].

(http://cultura.elpais.com/cultura/2014/05/29/actualidad/1401376682_746635.html)

In examples (20) and (21), personifications, nominalisations and agentless passive sentences are also used by British writers with the same purpose as that explained for the PenSp examples before:

[...] And the rest of the film offers (personification) an enormous amount of fun, energy and a bold sense of purpose [...].

(http://www.theguardian.com/film/2012/dec/09/hobbit-an-unexpected-journey-review)

[...] The impulse (nominalisation) to make "Philomena" may have been born out of upset (agentless passive sentence) Yet, it's resolved (agentless passive sentence) with a compassion that trips you up scene after scene [...].

(http://www.theguardian.com/film/2012/dec/09/hobbit-an-unexpected-journey-review)

\section{DISCUSSION AND CONCLUSION}

This paper has explored the rhetorical use of interpersonality in PenSp and BrE online movie reviews. Broadly speaking, the findings suggest that interpersonal metadiscourse differs between both languages in the use of hedges and attitude markers.

As for hedges, politeness considerations concerning the use of positive and negative linguistic devices (Brown and Levinson 1987) along with the individualistic scores of 
Spain (51) and the UK (89) seem to have an influence in the way Peninsular-Spanish and British professional writers include these types of interactional markers in movie reviews.

The results may be apparently linked to the two types of social self-image that linguists Scollon and Scollon (1995) established in their study of linguistic politeness from an intercultural perspective: (a) involvement and (b) independence. The former concerns the speaker's right and need to be a cooperative member in any communicative act (positive image). The latter, on the contrary, highlights the speaker's right to be free from the imposition of others and keep his/her own space (negative image).

On the BrE corpus hedges are used to "minimise the illocutionary purpose of the speech act" (Spencer-Oatey 2008: 25-27). This consists in persuading readers either to watch or not to watch the movie. In this sense, the high individualism index of the British (89) could be reflected in the way writers provide readers with the necessary freedom of action to accept or refute the ideas transmitted in the text pointing to a negative linguistic politeness culture.

PenSp writers often appear to refrain themselves from understating their statements when reviewing movies and the information seems as if it were more overtly expressed. This could be partly due to Spain's moderate index of individualistic values (51). The Peninsular-Spanish culture has a mixture of individualistic and collectivist cultural values and direct linguistic strategies are interpreted as positive linguistic politeness. In other words, in societies more oriented to collectivist cultural values, like Spain, it is normally assumed that the receiver will carry out the act asked by the sender of the message (e.g. Díaz-Pérez 2003; Márquez-Reiter 2000; Vázquez-Orta 1995). As such, the overt expressions included in the PenSp film reviews would be accepted by PenSp readers because of their cultural framework. This leads us to consider that the positive image of readers is much more emphasised than in the BrE corpus.

The high score of individualistic cultural values of the UK (89) and its low-context cultural orientation are reflected in the way the BrE movie reviews include a wider range of attitude markers. If we compare these findings with the ones obtained in the PenSp data set, we notice that the latter employs attitude nouns in higher frequencies. This might mean that British writers tend to explicitly transmit their own opinions of their film reviews to potential readers. This can be related to one fundamental issue: the explicit communicative style that speakers from individualistic societies make use of to communicate (Caillat and Mueller 1996; De Mooij 2000; Usunier and Lee 2005). In other words, in individualistic cultures the free expression of one's own thoughts is a sign of sincerity and honesty (Hofstede 1991; Walker et al. 2003).

Regarding the use of boosters, the findings do not reveal any statistical differences between both data sets. This makes us believe that this type of interactional marker could be more constrained by the peculiarities of the movie review genre. Therefore, boosters might be considered a fundamental property of this type of text to achieve the persuasion of the reader. Despite this, the higher frequency of intensifying adjectives found in the PenSp corpus and its highly significant differences with respect to its BrE counterpart may give rise to another interpretation. As Spain favours a fairly high-context culture where its speakers rely on a more implicit style to communicate their message, we agree with Suau-Jiménez (2010: 7) in that these types of adjectives may be used to "provide a sort of subjective modulation to the propositional content". PenSp writers would rather use these 
markers in their movie reviews to implicitly attract the attention of their readers and achieve the persuasion of the latter.

In relation to the use of engagement and self-mention markers, both corpora use a low frequency of these interactional markers, which may imply that these are not prototypical rhetorical elements of the movie review genre. Nevertheless, when looking at the findings obtained in the use of implicit engagement markers and depersonalisation strategies, both data sets show higher occurrences in the use of these strategies.

Peninsular-Spanish writers resort to the use of a third person in discourse as well as personifications, impersonal passive sentences and nominalised sentences. This could be due to the fact that Spain is a fairly high context culture which favours a more implicit communicative style. By the same token, British writers also make use of a generic second-person reference to implicitly engage with their readers as well as agentless passive sentences to depersonalise the information contained in their film reviews.

The above findings lead us to partially answer the first research question regarding Spaniards' and Britons' degree of contextual dependence and individualistic index on the interactional metadiscourse strategies included in PenSp and BrE reviews. In spite of the fact that British writers use hedges and attitude markers as a result of their high individualistic cultural values and low-context orientation, their preference for using implicit engagement markers and depersonalisation strategies make British writers share some similarities with their Peninsular-Spanish peers, at least as far as interpersonality in the online movie review genre is concerned. However, it is worth considering that these similar interactional markers are not exactly expressed through the same linguistic devices in both data sets as our analysis has actually proved.

Another possible interpretation of our results is that although Britons are individualistic, their negative politeness system (Brown and Levinson 1987; House and Kasper 1981: 157-185; Vázquez-Orta 1995: 20) and less low-context dependence (Guillén-Nieto 2005: 114; Lewis, 1996: 184) —if compared, for example, with North Americans — would possibly make Britons less explicit than their US counterparts in terms of communication and share some similarities with Spaniards.

Our findings may also be compared to those obtained by Carretero (2014). The linguist reaches the conclusion that professional reviewers, like the ones examined in this study, write in a more impersonal way and experiences and impressions are hardly communicated. This would answer our second research question: even though PenSp and BrE online movie reviews include different interactional metadiscourse strategies as a result of their different cultural frameworks, similarities are also observed. These may be due to the constraints imposed by the particular genre.

As regards the third research question, that is, the implications for the teaching and learning of L2 writing skills, we feel that the findings of this study can make students be aware of the important role that metadiscourse plays in the successful outcome of a persuasive text. Despite L2 learners are frequently encouraged to write a good film review taking into account the layout as well as the appropriate morpho-syntax and lexical choices of the target language, their socio-cultural competence could possibly fail due to an inappropriate use of interpersonal markers, as these may be transferred from their native language and the persuasion on the target reader may not be achieved at all. 
If culture filters the production and interpretation of interactional metadiscourse strategies in different languages, as this study has partly proved, the way to achieve persuasion will also differ between the students' mother tongue and the target language as the persuasive effect may also be constrained by culture. Nevertheless, as the results of the study also reveal similarities in the use of interpersonal strategies, this fact makes us object, in some way, to the bipolar cultural orientations that have been frequently used to categorise nationalities from a cross-cultural perspective such as those of Hall (1976) and Hofstede (1991).

L2 teachers should not consider the use of cultural values as the only factors influencing the use of rhetorical strategies in different languages. Within a culture, there could be many situational contexts in which the traditional dichotomy of cultural values may not be applied at all (Holliday 1999). In this vein, Hall's and Hofstede's cultural values may be a useful starting point to do research in cross-cultural communication. Yet, other influential contextual variables like the constraints imposed by the peculiarities of the genre or discipline should also be addressed for teaching professional writing skills in the second language.

In future research it would be interesting to observe if similar results would be obtained with a corpus consisting of consumer-generated movie reviews rather than professional ones. The impact of cultural values on the general layout or the organisation of the different communicative moves in the movie review genre could be worth analysing. Other professional and academic genres could be the object of analysis to know whether the use of interpersonal metadiscorse is constrained by culture, genre or a combination of both. Finally, we could provide local readers from England and Spain with a literal translation of the movie reviews examined and observed, through the use of questionnaires, their own impressions when they process and interpret the information contained in this particular genre. In our opinion, this would lead us to a more socio-linguistic study.

\section{REFERENCES}

BENNET, M. J. 1998. "Intercultural communication: a current perspective". Basic Concepts of Intercultural Communication. Selected Readings. Ed. J.M. BENNET. Yarmouth, Maine, USA: Intercultural Press, Inc. 1-34.

BHATIA, VIJAY K. 1993. Analyzing Genre: Language Use in Professional Settings. London: Longman.

BLUM-KULKA, S., J. HOUSE, and G. KASPER. 1989. Cross-Cultural Pragmatics: Requests and Apologies. Norwood, New Jersey: Ablex Publishing Corporation.

BROWN, P. and S. LEVINSON. 1987. Politeness. Some Universals in Language Use. Cambridge: Cambridge University Press.

CAILLAT, Z. and B. MUELLER. 1996. "The influence of culture on American and British advertising: an exploratory comparison of beer advertising". Journal of Advertising Research, 36/3: 79-88.

CARRETERO, M. 2014. "The role of authorial voice in professional and non-professional reviews of films: an English-Spanish contrastive study of engagement". 
Dialogicity in Written Specialised Genres. Eds. L. GIL-SALOM and C. SOLERMONREAL. The Netherlands: John Benjamins Publishing Company. 55-68.

CLARK, T. 1990. "International marketing and national character: a review and proposal for an integrative theory". Journal of Marketing, 50: 66-79.

CLYNE, M. 1994. Intercultural Communication at Work. Cultural values in Discourse. USA: Cambridge University Press.

CONNOR, U., E. NAGELHOUT and W. ROZYCKI. 2008. Contrastive Rhetoric: Reaching to Intercultural Rhetoric. Amsterdam/Philadelphia: John Benjamins Publishing Company.

CRISMORE, A. 1989. Talking with Readers: Metadiscourse as Rhetorical Act. New York: Peter Lang.

CRISMORE, A., R. MARKANNEN and M. STEFFENSEN. 1993. "Metadiscourse in persuasive writing. A study of texts written by American and Finnish university students". Written Communication, 10/1: 39-71.

DAFOUZ-MILNE, E. 2003. "Metadiscourse revisited: a contrastive study of persuasive writing in professional discourse". Estudios Ingleses de la Universidad Complutense, 11: 29-52.

2006. "Estudio de los marcadores interpersonales en el comentario periodístico: estrategias para la identificación autor-lector en el texto". Resla, 19: 67-82.

DE MOOIJ, M. 2000. “The future is predictable for international marketers: converging incomes lead to diverging consumer behavior". International Marketing Review, 17/2: 103-113.

DÍAZ-PÉREZ, F.J. 2003. La Cortesía verbal en inglés y en español. Actos de habla y pragmática intercultural. Jaén: Publicaciones de la Universidad de Jaén.

GARCÍA, F. 1985. Cómo escribir para la prensa. Madrid: Ibérico Europea de Ediciones.

GARCÍA-YESTE, M. A. 2013. "Press advertisement for food in Spain: cultural orientations and communicative style". Ibérica, 26: 195-216.

GIBSON, R. 2000. Intercultural Business Communication. Oxford: Oxford UP.

GIL, L., C. SOLER and K. STUART. 2004. TextWorks. Valencia. Departamento de Idiomas.

GIMÉNEZ-MORENO, R. and H. SKORCZYNSKA. 2013. "Business communication across three European cultures: A contrastive analysis of British, Spanish and Polish email writing". Ibérica, 26: 77-98.

GIOVANNINI, A., E. MARTÍN, M. RODRÍGUEZ and T. SIMÓN. 1996. Profesor en acción 1: el proceso de aprendizaje. Madrid: Edelsa.

GRICE, P. 1975. "Logic and conversation.” Syntax and Semantics: Speech Acts. Eds. P. COLE and J. MORGAN. New York: Academic. 45-47 
GUILLÉN-NIETO, V. 2005. “The invisible face of culture: why do Spanish toy manufacturers believe the British are most peculiar in business?" Thistles: A Homage to Brian Hughes. Eds. J. MATEO and F. YUS. Universidad de Alicante: Departamento de Filología Inglesa. 95-127.

2013. "Intercultural business pragmatics: The case of the business letter of introduction". Research Trends in Intercultural Pragmatics. Eds. I. KECSKES and J. ROMERO-TRILLO. Berlín: Mouton De Gruyter. 395-420.

HALL, E. T. 1959. The Silent Language. New York: Doubleday. 1966. The Hidden Dimension. New York: Doubleday. 1976. Beyond Culture. New York: Anchor.

HALLIDAY, M. 1975. "Language as social semiotic: towards a general sociolinguistic theory". The First LACUS Forum. Eds. A. MAKKAI and V. BECKER. Columbia: Hornbeam Press. 17-46.

HAMPDEN-TURNER, CH. and F. TROMPENAARS. 2000. Buiding Cross-Cultural Competence. How to Create Wealth from Conflicting Values. Chichester: John Wiley and Sons, Ltd.

HOFSTEDE, G. 1991. Culture and Organizations: Software of the Mind. London: Profile Books.

HOLLIDAY, A. 1999. "Small cultures”. Applied Linguistics, 20/2: 237-264.

HOOPES, D. 1980. "Intercultural communication concepts and the psychology of intercultural experience". Multicultural Education: A Cross-Cultural Training Approach. Ed. M. E. PUSCH. La Grange Park, IL: Intercultural Press.

HOUSE, J. and G. KASPER. 1981. "Politeness markers in English and German". Conversational Routine. Eds. F. COULMAS. The Hague: Mouton. 157-185.

HYLAND, K. 1998. "Persuasion and context: The pragmatics of academic metadiscourse". Journal of Pragmatics, 30: 437-55

1999. "Talking to students: metadiscourse in introductory coursebooks". English for Specific Purposes, 18/1: 3-26.

HYLAND, K. and T.POLLY. 2004. "Metadiscourse in academic writing: a reappraisal". Applied Linguistics, 25/2: 156-177.

IVORRA-PÉREZ. 2012. "Reaching to intercultural rhetoric: teaching cultural values to students of English in their writing compositions" Proceedings of the 12th Conference of the European Association of Specific Purposes (AELFE), 27-35.

2014. "Cultural values and their correlation with interactional metadiscourse strategies in Spanish and US business websites". Atlantis, 36/2: 73-95.

2015. "The impact of cultural dimensions on the engagement markers of Spanish, British and US toy selling websites". A Multidisciplinary Approach to Service 
Encounters. Eds. M.O. HERNÁNDEZ-LÓPEZ and L. FERNÁNDEZ-AMAYA. Leiden/Boston: Brill. 141-163.

JUNQUEIRA, L. and V. CORTÉS. 2014. "Metadiscourse in book reviews in English and Brazilian Portuguese: a corpus-based analysis". Rhetoric, Professional Communication and Globalization, 6: 88-109.

KAPLAN, R.B. 1966. “Cultural thought patterns in intercultural education”. Language Learning, 16/1: 1-20.

KLUCKHON, F.R. and F.Z. STRODBECK. 1961. Variations in Value Orientations. Wesport, CT: Greenwood Press.

LEWIS, R. D. 1996. When Cultures Collide: Managing Successfully across Cultures. USA: Nicholas Brealey International.

LOUKIANENKO-WOLFE, M. 2008. "Different culture-different discourses. Rhetorical patterns of business letters by English and Russian speakers". Contrastive Rhetoric. Reaching to Intercultural Rhetoric. Eds. U. COONOR, E. NAGELHOUT and W. ROZYCKI.Amsterdam/Philadelphia: John Benjamins Publishing Company. $87-121$.

MÁRQUEZ-REITER, R. 2000. "Politeness phenomena in British English and Uruguayan Spanish: the case of requests". A Journal of English and American Studies, 18: $159-167$.

MARTÍN, G. 1986. Curso de redacción. Madrid: Paraninfo.

MAURANEN, A. 1993. Cultural Differences in Academic Rhetoric. Frankfrurtam Main: Peter Lang.

MORÁN, E. 1988. Géneros del periodismo de opinión. Pamplona: Eunsa.

MORENO,A. I. 1997. “Genre constraints across languages: causal metatext in Spanish and English Ras”. English for Specific Purposes, 16/3: 161-179.

MUR-DUEÑAS, P. 2010. "Attitude markers in business management research articles: a cross-cultural corpus-driven approach". International Journal of Applied Linguistics, 20/1: 50-72.

PRINCE, E., J. FRADER and Ch. BOSK. 1982. "On hedging in physician-physician discourse". Proceedings of the Second Annual Delaware Symposium on Language Studies. Eds. J. ROBERT and D. PIETRO. Ablex Publishing Corporation, Norwood NJ: Ablex. 83-97.

PRYKARPATSKA, I. 2008. "Why are you so late?: cross-cultural pragmatic study of complaints in American English and Ukrainian". Revista Alicantina de Estudios Ingleses, 21: 87-102.

SCOLLON, R. and S. SCOLLON. 1995. Intercultural Communication. Oxford UK and Cambridge USA: Blackwell. 
SCOLLON, R., S. WONG SCOLLON and R. H. JONES. 2012. Intercultural Communication. A Discourse Approach. Wiley-Blackwell.

SHOKOUHI, H. and A. TALATI. 2009. "Metadiscourse functions in English and Persian sociology articles: a study in contrastive rhetoric". Poznan Studies in Contemporary Linguistics, 45/4: 549-568.

SPENCER-OATEY, H. 2008. Culturally Speaking: Culture, Communication and Politeness Theory. New York: Continuum.

SUAU-JIIMÉNEZ, F. and R. DOLÓN-HERRERO. 2007. "The importance of metadiscourse in the genre 'Promotion of Touristic Services and Products': differences in English and Spanish". Languages for Specific Purposes: Searching for Common Solutions. Ed. D. GALOVÁ. Newcastle, UK: Cambridge Scholar Publishing.

SUAU-JIMÉNEZ, F. 2010. La traducción especializada (en inglés y español en géneros de economía y empresa). Madrid: Arco/Libros, S.L.

2016. "What can the discursive construction of stance and engagement voices in traveller forums and tourism promotional websites bring to a cultural, cross-generic and disciplinary view of interpersonality?". Ibérica, 31: 199-220.

SWALES, J. 1990. Genre Analysis: English in Academic and Research Settings. New York: Cambridge University Press.

USUNIER, J. and A. L. JULIE. 2005. Marketing across Cultures. Harlow: Pearson Education.

VALERO-GARCÉS, C. 1996. “Contrastive ESP rhetoric: metatext in Spanish-English economic texts”. English for Specific Purposes, 15/4: 279-294.

vAN EK, J. 1986. Objectives for Foreign Language Learning. Strasbourg: Council of Europe.

VANDE-KOPPLE, W. 1985. "Some exploratory discourse on metadiscourse". College Composition and Communication, 36: 82-93.

VÁZQUEZ-ORTA, I. 1995. A Contrastive Study of Politeness Phenomena in England and Spain. Duisburg: University of Duisburg.

WALKER, D, W. THOMAS and J. SCHMITZ. 2003. Doing Business Internationally. The Guide to Cross-Cultural Success. New York: McGraw Hill.

WIERZBICKA, A. 1991. Cross-Cultural Pragmatics. The Semantics of Human Interaction. Berlin and New York: Mouton de Gruyter.

ZHANG, C. 2013. A Corpus-based Interactional Metadiscourse Analysis of Professional Movie Reviews in English. PhD Dissertation.

http://www.dissertationtopic.net/doc/1878868

ZUO, Y. 2011. Metadiscourse in English Movie Reviews. PhD Dissertation. http:// www.p-papers.com/19385.html 